\title{
Occurrence and Detection of Killer Yeasts on Chenin Blanc Grapes and Grape Skins
}

\author{
C.J. Jacobs ${ }^{1}$, I. Fourie ${ }^{1}$ and H.J.J. van Vuuren ${ }^{2}$ \\ 'Stellenbosch Farmers' Wineries, P.O. Box 46, Stellenbosch 7600, South Africa and \\ ${ }^{2}$ Department of Microbiology, University of Stellenbosch, Stellenbosch 7600, South Africa \\ Date submitted for publication: August 1988 \\ Date accepted for publication: September 1988 \\ Keywords: killer yeast, grape must, grapes
}

\begin{abstract}
Two hundred and thirty killer yeast strains were selectively isolated from Chenin blanc grapes and grape skins collected from six wineries. The killer yeasts were divided into nine groups based on their colony morphology and colour on modified Wallerstein laboratory nutrient agar. All strains fermented Chenin blanc grape must (pH 3,5; $40 \mathrm{mg} / \mathrm{l}$ free $\mathrm{SO}_{2}$ and $5 \%(\mathrm{v} / \mathrm{v})$ ethanol) at $14^{\circ} \mathrm{C}$. Existing techniques in which methylene blue are used were evaluated to detect killer yeasts, to determine interactions between different killer phenotypes, and to determine the sensitivity of commercial strains to the killer toxins.
\end{abstract}

Killer (K), sensitive (S), and neutral (N) phenotypes of Saccharomyces cerevisiae were first described by Bevan \& Makower (1963). Killer yeasts were thereafter shown to be widespread amongst laboratory strains of this species (Fink \& Styles, 1972). Subsequently, killer-sensitive (K-S) strains were discovered (Woods, Ross \& Hendry, 1974). These strains are immune to their own toxins but may be sensitive to toxins of other killer strains. The killer property is also present in other yeast genera such as Candida, Debaryomyces, Hansenula, Kluyveromyces, Pichia, Torulopsis and Cryptococcus (Philliskirk \& Young, 1975; Rosini, 1983; Stumm et al., 1977). Killer interactions are generally restricted between strains of species within a genus, but interactions between species of different genera have been reported (Bussey, 1974; Mitchell \& Bevan, 1983; Tipper \& Bostian, 1984).

Killer yeasts secrete a proteinacious killer toxin lethal to susceptible or sensitive strains of the same species, but are immune to their own toxin (Bevan \& Makower, 1963). The genetic determinants encoding for both the killer toxin and the factor conferring immunity to the cell reside in virus-like particles (VLP) occurring in the yeast cell cytoplasm (Mitchell \& Bevan, 1983). It was previously suspected that VLP's are non-infectious, however, El-Sherbeini \& Bostian (1987), more recently showed that they are true mycoviruses.

The killer toxin is inactive against other eucaryotes and no pharmacological activity was detected in tests conducted on various animal organs (Pfeiffer et al., 1988). The properties of killer toxins, have been used to classify killer yeasts into at least 11 groups $\left(\mathrm{K}_{1}-\mathrm{K}_{\mathrm{II}}\right)$. Three of these $\left(\mathrm{K}_{1}, \mathrm{~K}_{2}\right.$ and $\left.\mathrm{K}_{3}\right)$ are specific to Saccharomyces cerevisiae (Naumov \& Naumova, 1973; Rogers \& Bevan 1978; Stumm et al., 1977; Young \& Yagiu, 1978). The optimum $\mathrm{pH}$ for production and stability of toxins of group $\mathrm{K}_{\mathrm{I}}$ ranges between 4,6 and 4,8 (Woods \& Bevan, 1968) and is therefore not important in winemaking. However, the optimum pH for the $\mathrm{K}_{2}$ and $\mathrm{K}_{3}$ toxins varies between pH 2,9 and 4,9 (Shimizu et al., 1985), and might pose a threat to the wine industry.

In 1986 Van Vuuren \& Wingfield reported a case where a $K_{2}$ killer yeast was responsible for protracted and stuck wine fermentations. They showed that the wild killer yeast ( T 206) significantly reduced the population of a sensitive strain (Geisenheim) in grape juice fermentations, even when the initial concentration of killers had comprised only $0,2 \%$ of the sensitive strain. However, Tredoux, Tracey \& Tromp (1986), reported that the commercially available killer yeasts WE 14 and WE 372, did not influence fermentations if present at concentrations lower than $2,5 \%$ of the sensitive strain (WE 500). Heard \& Fleet (1987), found that the killer effect is not noticeable when the ratio of killer to sensitive cells at the commencement of fermentation was as high as 1:7. Pronounced killer activity however, occurred when the ratio of killer to sensitive cells was approximately equal.

Killer yeasts could be used as starter cultures to control the growth of yeast contaminants during the early stages of wine fermentation (Hara, Iimura \& Otsuka, 1980; Hara et al., 1981; Seki Choi \& Ryu, 1985). If fermentations are to be conducted with sensitive strains, protein adsorbing substances such as bentonite or yeast cell walls, might be added beforehand to adsorb killer toxins from the medium (Radler \& Schmitt, 1987). Apart from a few reports, the occurrence and enological significance of killer strains of Saccharomyces cerevisiae in wineries remain unclear.

Based on colony morphology and colour on modified Wallerstein laboratory nutrient agar, we divided the killer yeast isolates into nine distinct groups. The interactions between strains of these groups with reference to killer yeasts, sensitive strains and commercial strains are reported. In addition different techniques were evaluated to assay toxin production.

\section{MATERIALS AND METHODS}

\section{Reference yeast strains:}

Reference strains of $\mathrm{K}_{1}$ (NCYC 323), $\mathrm{K}_{2}$ (NCYC 738) and $\mathrm{K}_{3}(\mathrm{NCYC} 761)$ as well as a $\mathrm{K}_{1}$ neutral strain (TM 2264) were obtained from Brenda Wingfield, Institute for Biotechnology, University of Stellenbosch. Commercially available killer yeasts WE 14 and WE 372 were also included. Three strains of Saccharomyces cer- 
evisiae (WE 500, 228, and a strain from Geisenheim) were used as the sensitive strains throughout this study.

All strains were kept on rich yeast medium (RYM) agar slants $(1 \%$ glucose, $0,5 \%$ Bacto peptone, $0,3 \%$ malt extract, $0,3 \%$ yeast extract and $1,5 \%$ Bacto agar) at $5^{\circ} \mathrm{C}$.

\section{Isolation of killer yeasts from Chenin blanc grapes and grape skins}

Ten bunches of sound Chenin blanc grapes and 10 samples of pressed grape skins were collected from each of six farms in the Stellenbosch area, and transported to the laboratory in sterile "Whirlypaks" (Millipore). Each sample was washed in $100 \mathrm{ml}$ sterile distilled water. One millilitre of undiluted suspension was added to a sterile selective enrichment medium which consisted of $15 \mathrm{ml}$ Chenin blanc must $\left(23,5^{\circ} \mathrm{Brix}\right.$; $\mathrm{pH}$ 3,$5 ; 40 \mathrm{mg} / \mathrm{l}$ free $\mathrm{SO}_{2}$ ) containing $50 \mathrm{mg} / l$ chloramphenicol (Sigma) and $50 \mathrm{mg} / \mathrm{l}$ penicillin-G (Sigma). Five percent $(\mathrm{v} / \mathrm{v})$ ethanol was added to the medium to inhibit fungus growth. Containers were incubated for 30 days at $14^{\circ} \mathrm{C}$.

The number of viable yeast cells was determined by microscopic counts of methylene blue stained samples (Anon, 1971). The suspensions were then diluted accordingly and $100 \mu l$ plated out on M-WLN medium (Difco Wallerstein nutrient medium modified by increasing bromocresol green to $0,01 \%$ ) to yield ca. 40 colonies per plate. The plates were incubated at $30^{\circ} \mathrm{C}$ for 2 days and kept for a further 12 days at $20^{\circ} \mathrm{C}$. Isolates were made from colonies differing in topography and colour on M-WLN medium. To test for killer activity these strains were transferred to methylene blue agar plates (MBA) seeded with a sensitive strain of Saccharomyces cerevisiae. One strain from each group was selected at random to evaluate 4 methylene blue techniques to determine killer phenotype and to study interactions between killer yeasts and sensitive strains.

\section{Culture preparation}

Killer and sensitive yeast strains were cultured separately in $100 \mathrm{~m} l$ Erlenmeyer flasks containing $40 \mathrm{~m} l$ sterile RYM medium ( $\mathrm{pH} \mathrm{6,63).} \mathrm{These} \mathrm{flasks} \mathrm{were} \mathrm{incu-}$ bated at $20^{\circ} \mathrm{C}$ for $48 \mathrm{~h}$.

\section{Seeded agar phenotype test}

The method described by Van Vuuren \& Wingfield (1986) was used.

\section{Well test}

The technique of Philliskirk \& Young (1975) was used to assay for the killer factor in liquid medium. The seeded agar $(\mathrm{pH} 4.5)$ contained $1 \times 10^{4}$ cells $/ \mathrm{m} l$ of the sensitive strain.

\section{Seeded PYG technique}

The method of Russel \& Steward (1986) was used.

\section{Atomizer technique}

The agar base medium was the same as that described by Van Vuuren \& Wingfield (1986). Plates were dried at $30^{\circ} \mathrm{C}$ for $24 \mathrm{~h}$. Three $\mu l$ samples of killer yeast cells (concentrated by sedimentation) were spotted on the agar base. Plates were incubated at $20^{\circ} \mathrm{C}$ for $24 \mathrm{~h}$. A lawn of sensitive yeast cells was applied with a Unispray atomizer (Camag, Cat. 26810). Plates were reincubated at $20^{\circ} \mathrm{C}$ for $24 \mathrm{~h}$.

\section{RESULTS AND DISCUSSION}

Two hundred and thirty killer yeast strains were isolated from Chenin blanc grapes and grape skins collected from six South African wineries. This supports other reports on the widespread nature of killer yeasts (Heard \& Fleet, 1987; Naumov \& Naumova, 1973; Van Vuuren \& Wingfield, 1986) in the wine industry. Killer yeasts were isolated from each of the wineries. Noteworthy $42 \%$ of the isolates were from grape skins. In contrast, Kitano et al., (1984) were unable to isolate killer yeasts from grapes collected at Japanese wineries. All the local killer isolates fermented Chenin blanc must ( $\mathrm{pH} 3.5)$ at $14^{\circ} \mathrm{C}$ and were resistant to $40 \mathrm{mg} / \mathrm{l}$ free $\mathrm{SO}_{2}$ and $5 \%(\mathrm{v} / \mathrm{v})$ ethanol. This indicates that they might flourish under vinification conditions. The killer property is known to be effectively expressed under wine fermentation conditions (Heard \& Fleet, 1987) and that killer yeasts can cause stuck wine fermentations (Van Vuuren \& Wingfield, 1986). The widespread occurrence of killer yeasts might thus be of economic significance especially if sensitive yeast strains are used to inoculate grape must. Colonies of certain killer yeast isolates display a distinct morphology and colourization on M-WLN medium, due to the selective uptake of bromocresol green. After incubation colony topography varied from smooth apical to rough mesa. Furthermore, colonies from different isolates varied from white, through yellow and green to a deep black colour (Fig. 1). Heard and Fleet (1987) differentiated between several killer strains, based on morphological appearance of colonies on malt extract agar. These differences, however, were described as subtle. In contrast, we found marked and reproducible morphological and colour differences between killer groups. These differences are currently being consider-

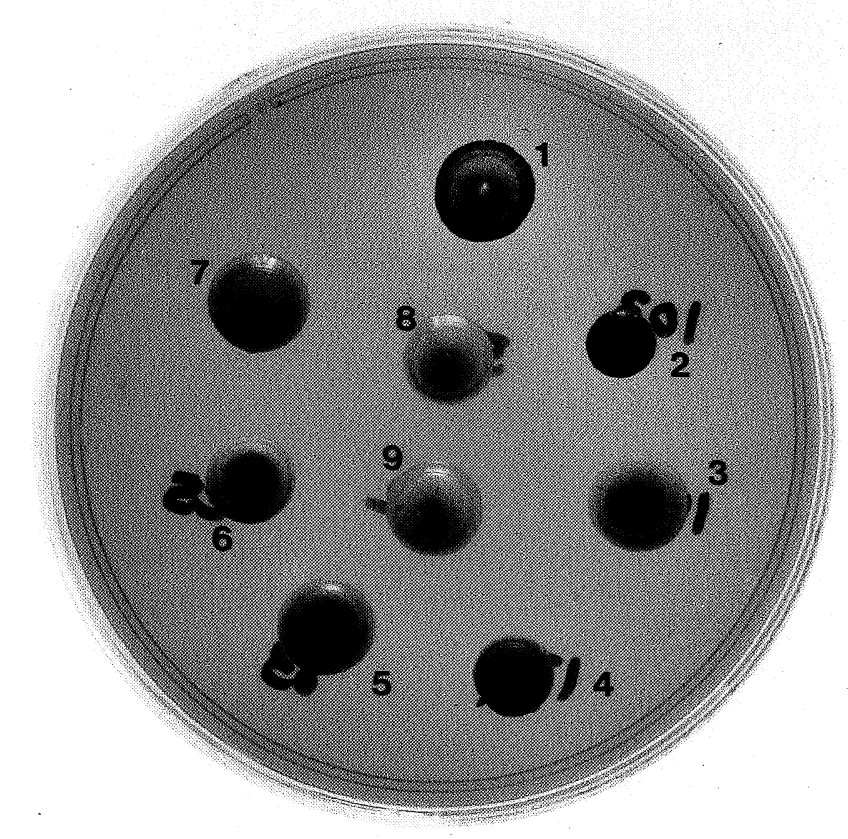

FIG. 1

Different colour and morphological types of killer yeasts on M-WLN medium (Groups 1 to 9 ). 
ed as a method to distinguish between killer and sensitive strains during mixed culture fermentations.

Colony morphology and colour on M-WLN medium were used to assign 87 of the killer yeast isolates into nine distinct groups (Fig. 1). These isolates are now being characterized by numerical analysis of total soluble cell proteins and gas chromatography of cellular fatty acids. The seeded phenotype test used by Van Vuuren \& Wingfield (1986) to detect killer yeasts in commercially fermenting grape must, proved to be the most

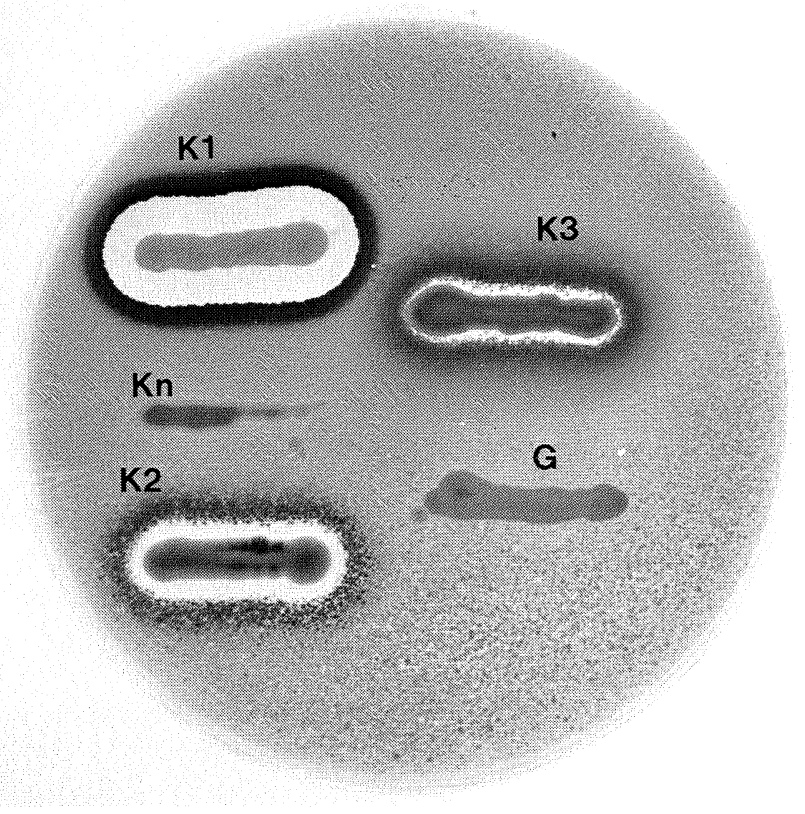

FIG. 2

The seeded agar phenotype test used for the rapid detection of killer yeasts. $K_{1}, K_{2}, K_{3}$ and $K_{n}$, represent the reference strains used to inoculate methylene blue-containing plates previously spread with a sensitive yeast from Geisenheim $(\mathrm{G})$.

rapid (48 h) detection method. However, to observe a clear-cut reaction it is necessary to concentrate the yeast cells by centrifugation or sedimentation, before streaking onto the lawn of sensitive cells (Fig. 2).

The PYG technique was most suitable for testing interactions between different killer yeasts. The commercial killer yeasts (WE 14 and WE 372) and the wild

TABLE 1

Cross reactions of commercial and wild killer yeasts with $K_{1}, K_{2}, K_{3}$ and a $K_{1}$ neutral strain.

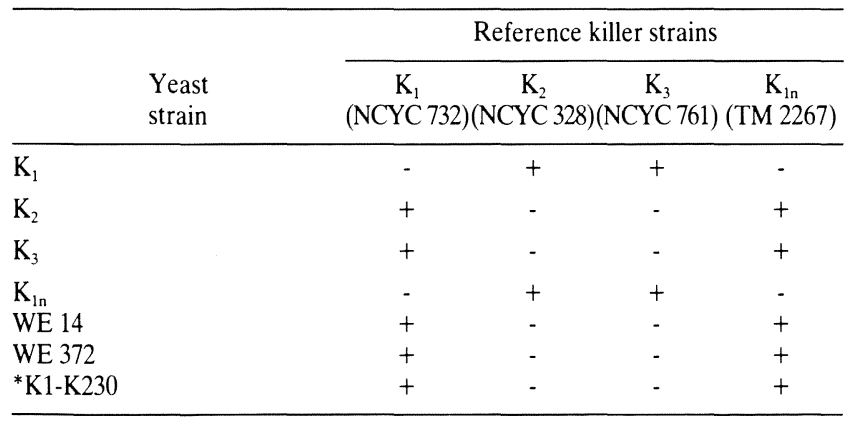

(+) Inhibition zones on methylene blue-containing agar plates.

$(-) \quad$ No inhibition zones.

* $\quad$ Killer yeasts isolated from Chenin blanc grapes. killer yeasts did not interact. Cross reactions of commercial killers and wild killers with $\mathrm{K}_{1}, \mathrm{~K}_{2}, \mathrm{~K}_{3}$ and the $\mathrm{K}_{1}$-neutral strains, indicated that the wild and commercial killer yeasts belonged either to the $K_{2}$ or $K_{3}$ group (Table 1).

The atomizer and the well test techniques proved to be the most suitable to indicate the amount of toxin

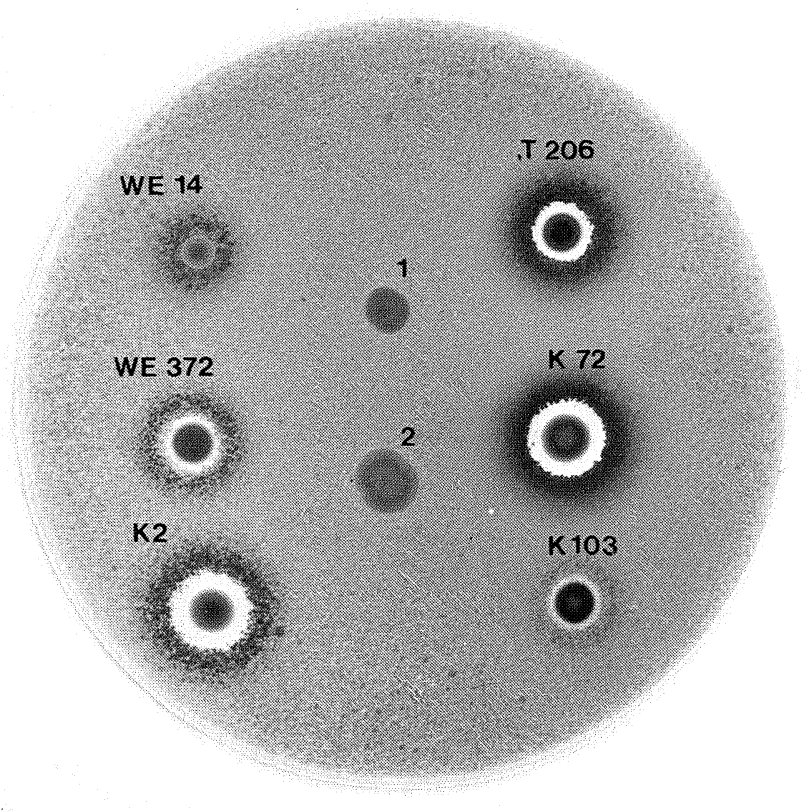

FIG. 3

The atomizer technique used to compare killer toxin production between different killer yeasts. Methylene blue-containing plates were previously sprayed with a sensitive Geisenheim yeast ( 1 and 2 ), and inoculated. T206, K-72 and K-103 are wild killer yeasts, WE 14, and WE 372 commercially available killer yeasts, and $K_{2}$ a reference strain.

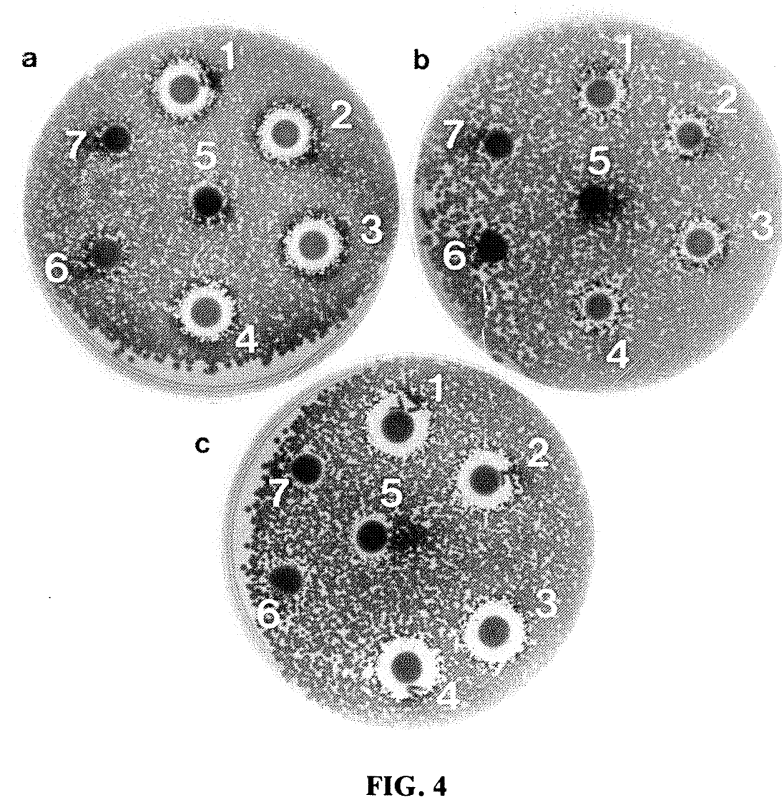

The effect of killer yeasts ( 1 to 5 ) on three different sensitive yeast strains: (a) Geisenheim, (b) WE 500 and (c) 228.

$\begin{array}{lllll}= & \text { K-72 } & 5 & = & \text { WE 14 } \\ = & \mathrm{T}-206 & 6 & = & \text { Geisenheim } \\ = & \text { K-45 } & 7 & = & \text { WE 500 } \\ = & \text { K-5 } & & & \end{array}$


produced. The wild killer yeasts produced considerably more toxin than the commercial killers (Fig. 3).

These techniques also proved to be effective for testing the degree of sensitivity of the sensitive strains. Saccharomyces cerevisiae 228 and a strain from Geisenheim were much more sensitive to the killer toxin than WE 500 (Fig. 4). This phenomenon might explain the conflicting reports of Van Vuuren \& Wingfield (1986) and Tredoux, Tracey \& Tromp (1986).

In conclusion, our results confirm those of Heard \& Fleet (1987) that considerable heterogeneity exists among $\mathrm{K}_{2}$ killer strains with respect to their ability to kill different sensitive strains. The use of sensitive yeast strains such as WE 500 and 228 currently employed by the South African wine industry, could lead to protracted or stuck fermentations caused by killer yeasts. Preference should possibly be given to neutral strains or to killer yeasts possessing desirable oenological properties.

\section{LITERATURE CITED}

ANON, 1971. Recommended methods of analysis. J. Inst. Brew. 77, 81-226.

BEVAN, E.A. \& MAKOWER, M., 1963. The physiological basis of the killer character in yeasts. In: Geerts, S.J. (ed.) Genetics Today, XIth int. Congr. Genet., Vol. I, Pergamon Press, Oxford pp 202-203.

BUSSEY, H., 1974. Yeast killer factor-induced turbidity changes in cells and sphaeroplasts of a sensitive strain. J. Gen. Microbiol. 82, 171-179.

EL-SHERBEINI, M. \& BOSTIAN, K.A., 1987. Viruses in fungi: Infection of yeast with $\mathrm{K}_{1}$ and $\mathrm{K}_{2}$ killer virusses. Proc. Natl. Acad. Sci. U.S.A. 84, 4293-4297.

FINK, G.R. \& STYLES, C.A., 1972. Curing of a killer factor in Saccharomyces cerevisiae. Proc. Nat. Acad. Sci. U.S.A. 69, 2846-2849.

HARA, S., Y. IIMURA, \& OTSUKA, K., 1980. Breeding of useful killer wine yeasts. Am. J. Enol. Vitic. 31, 28-33.

HARA, S., IIMURA, Y., OYAMA, H., KOZEKI, T., KITANO, K. \& OTSUKA, K., 1981. The breeding of cryophilic killer wine yeasts. Agric. Biol. Chem. 45, 1327-1334.

HEARD, G.M. \& FLEET, G.H., 1987. Occurrence and growth of killer yeasts during wine fermentation. Appl. Environ. Microbiol. 53, 2171-2174.
KITANO, K., SATO, M., SHIMAZAKI, T. \& HARA, S., 1984. Occurrence of wild killer yeasts in Japanese wineries and their characteristics. J. Ferment, Technol. 62, 1-6.

MITCHELL, D.J. \& BEVAN, E.A., 1983. SCV Killer viruses in yeast. In: Spencer, J.F.T., Spencer, D.M. \& Smith, A.R.W (eds.) Yeast Genetics. Fundamental and Applied Aspects. Springer Verlag, New York, pp. 371-419.

NAUMOV, G.I. \& NAUMOVA, T.I., 1973. Comparative genetics of yeast communication. XIII. Comparative study of killer strains of Saccharomyces from different collections. Genetika. 9, $140-145$.

PFEIFFER, P., RADLER, F., CASPRITZ, G. \& HANEL, H., 1988. Effect of a killer toxin of yeast on eucaryotic systems. Appl. Environ. Microbiol. 54, 1068-1069.

PHILLISKIRK, G. \& YOUNG, T.W., 1975. The occurrence of killer character in yeasts of various genera. Antonie van Leeuwenhoek. J. Microbiol. Serol. 41, 147-151.

RADLER, F. \& SCHMITT, M., 1987. Killer toxins of yeasts: Inhibitors of fermentation and their adsorption. J. Food Protect. 50, 234-238.

ROGERS, D. \& BEVAN, E.A., 1987. Group classification of killer yeasts based on cross-reactions between strains of different species and origin. J. Gen. Microbiol. 105, 199-202.

ROSINI, G., 1983. The occurrence of killer characters in yeasts. Can. J. Microbiol. 29, 1462-1464.

RUSSELL, I. \& STEWARD, G.G., 1986. Killer yeast identification. Am. Soc. Brew. Chem. 44, 123-125.

SEKI, T., CHOI, E.H. \& RYU, D., 1985. Construction of killer wine yeast strains. Appl. Environ. Microbiol. 49, 1211-1215.

SHIMIZU, K., ADACHI, T., KITANO, K., SHIMAZAKI, T., TOTSUKA, A., HARA, S. \& DITTRICH, H.H., 1985. Killer properties of wine yeasts and characterization of killer wine yeasts. J. Ferment. Technol. 63, 421-429.

STUMM, C., HERMANS, J.M.H., MIDDELBECK, E.J., CROES, A.F. \& DE VRIES, G.J., 1977. Killer-sensitive relationships in yeasts from natural habitats. Antonie van Leeuwenhoek. J. Microbiol. Serol. 43, 125-128.

TREDOUX, H.G., TRACEY, R.P. \& TROMP, A., 1986. Killer factor in wine yeast and its effect on fermentation. S. Afr. J. Enol. Vitic. 7, 105-112.

TIPPER, D.J. \& BOSTIAN, K.A., 1984. Double-stranded ribonucleic acid killer systems in yeasts. Microbiol. Rev. 48, 125-156.

VAN VUUREN, H.J.J. \& WINGFIELD, B.D., 1986. Killer yeasts - Cause of stuck fermentations in a wine cellar. S. Afr. J. Enol. \& Vitic. 7, 113-118.

WOODS, D.R. \& BEVAN, E.A., 1968. Studies on the nature of the killer factor produced by Saccharomyces cerevisiae. J. Gen. Microbiol. 51, 115-126.

WOODS, D.R., ROSS, I.W. \& HENDRY, D.A., 1974. A new killer factor produced by a killer/sensitive yeast strain. J. Gen. Microbiol. 81, 285-289.

YOUNG, T.W. \& YAGIU, M., 1978. A comparison of the killer character in different yeasts and its classification. Antonie van Leeuwenhoek. J. Microbiol. Serol. 44, 59-77. 